\title{
The Educated Indigenous African Woman and the Issue of being Assertive as Showcased in Adeche's Purple Hibiscus?
}

\author{
Georgina Brookman-Andoh ${ }^{1}$, Martin Gyekye-Ampofo ${ }^{2}$ \\ ${ }^{1}$ Department of English, St Louis College of Education, Kumasi, Ghana \\ ${ }^{2}$ Department of Educational Innovations, Kwame Nkrumah University of Science and Technology, Ghana \\ gyekyeampofo14@gmail.com
}

Abstract: The research looked at the relevance of the indigenous African educated woman in contemporary African society: A case of Chimamanda Adeche's Purple Hibiscus. The purpose of the study was to use Adeche's Purple Hibiscus to showcase the position of the educated indigenous African educated woman in contemporary Africa. A qualitative approach was employed to look at views related to the indigenous African woman and her means of asserting herself through education and also adopted the traditional library research approach through the use of books, articles, journals and publications in as much as they contribute to the worth of the study. It was informed by the Feminist theory. The main findings of the study indicate that there have been positive changes in the roles of women over the years. This change has come about as a result of women's quest to assert themselves through education and contribute towards freeing their families from cultural and societal dogmas in which women were treated to subjugation and marginalization. A remarkable observation was the intentionality of ascribing to female characters more respectable roles in novels by various writers as the years go by. A conclusion drawn from the study is that education is still a major weapon of enhancing assertiveness in women but it is not the ultimate.

Keywords: Education, Educated Indigenous African woman, Assertive Woman, and Feminism.

\section{INTRODUCTION}

Feminism is strengthened lately in the African society since the African woman writer has now been able to come out with a presentation of pictures that truly portray women's self-definition. These provisions by African female writers encourage the process of carving self-images, insight and self-analysis into women's own experiences. According to Flora Nwapa's Women and Creative Writing in Africa (2007),

Women writers write about women because when we wake up in the morning and look into the mirror we see women. Female writers bring into focus their femaleness/femininity in their narratives and in doing so highlight power differences between men and women. As a result, women scholars and activists have pioneered intellectual revolution built on sexual politics aimed at stamping gender and feminism into both criticism and its philosophical appendagetheory, replacing a tradition that is masculine and domineering.

It is women's self-definition in this way that brought about the advocacy and expansion in development and growth in consciousness of the African female. It is therefore not surprising when African women writers consistently try to showcase issues about the ordeals of the woman in their various genres of literature.

African women writers concentrate on issues associated with the ordeals of the African woman and confront those works in which women were portrayed as being conditioned to be admired romantically and be used 
The Educated Indigenous African Woman and the Issue of being Assertive as Showcased in Adeche's Purple Hibiscus?

by men. Examples could be found in, Flora Nwapa's Efuru (1966), ${ }^{2}$ Buchi Emecheta's The Joys of Motherhood, (1977), ${ }^{3}$ Mariama Ba's So Long a Letter (1979) ${ }^{4}$ and Aiddoo's Anowa (1980). ${ }^{5}$ It is this growth in consciousness of the African female that caused African women writers of the continent to alter their presentation of the female into a symbol of social change and this change has mostly occurred through education and the assertive woman.

Evidently, African female writers and their recent writings such as Ba's Scarlet Song (1981) ${ }^{6}$, Emecheta's Double Yoke (1982) ${ }^{7}$,Aidoo's Changes, $(1991)^{8}$ Ama Darko's Faceless $(2003)^{9}$ and Adeche's Purple Hibiscus, $(2003)^{10}$ emphasize concerns with feminist issues; those that primarily educate about the impact of education on both rural and urban women. With the power of writing as a weapon to advocate change, they try to expose and resist difficulties arising out of suppression explained through the relationship of dominance and oppression.

The trend in the various works of examples of African female writers outlined from the above discussion showcases the levels of feminism from the twentieth century through to this current century in the African society.It is in view of this background that the study seeks to use Adiche's Purple Hibiscus to showcase how education gives relevance and appreciation to the contemporary African woman.

\section{THEORY}

The main theoretical framework is feminism and it is used concurrently with characterization and style to bring about the truism of the study. Feminism rejects the injustices in a patriarchal society and is concerned with issues of gender difference and campaigns for the rights of women. It seeks to address issues that deal with women's rights which have been trampled upon and specifically focuses on women's experiences and highlights various forms of oppression that the female gender is subjected to in the society. It is the oppression of women by patriarchy that culminated into the formulation of feminist ideas and thus considered deconstructing the established predominant rule of patriarchy, and constructed a female perspective which buttress female experience.

Virginia Woolf hammers on the discrimination against the exercising of the creative ability of women. Her work, A Room of One's Own (1929) ${ }^{11}$ introduced the notion of women education. According to her work, Woolf's father, Sir Leslie Stephen, in line with the thinking of the era, believed that only the boys of the family should be sent to school. Woolf encouraged the image of herself that because her father did not believe in investing in the education of his daughters, she was left without the experience of formal schooling. In delivering the lectures outline in the essay, Woolf is speaking to women who have the opportunity to learn in a formal, communal setting. She lets her audience know the importance of their education at the same time warning them of the precariousness of their position in society. She illustrates with a fictional character, Judith, Shakespeare's sister. She opines that with Shakespeare's gift, Judith as Shakespeare's sister could have had the same opportunity to develop her own talent but could not because of the doors that were closed to women. Judith stays at home while William goes to school. She was as adventurous, as imaginative, and as agog to see the world as he was and did but she was not sent to school. Her prose holds the hopes of Judith Shakespeare against her brother's hopes, abruptly curtails Judith's chances of fulfilling her promise with "but." While William learns, Judith is chastised by her parents should she happen to pick up a book, as she is inevitably abandoning some household chores to which she could be attending. Judith is betrothed, when she does not want to marry, she is beaten and shamed into marriage by her father. While Shakespeare established himself, Judith is trapped by the confines of the expectations of women. She kills herself and her genius goes unexpressed, while Shakespeare lives on and establishes legacy. If Judith was given the chance as did William, (people from the same biological background) those chances could have given the world two strong legacies. 
The Educated Indigenous African Woman and the Issue of being Assertive as Showcased in Adeche's Purple Hibiscus?

The study sits mainly on Woolf's theory and supports the fact that a range of factors in the environment conspire to impede women's competence and accomplishments in many areas: the hostile or deprecating attitudes of incumbent men, lack of support and assistance from all quarters that erodes confidence and self-assertiveness. Women are hampered in developing competence in most profound ways. It is for these reasons that some feminist thinkers like Adiche is extremely seeking to uncover this bias and restore balance with her novel. The following tenets of feminism pertain to the study:

- Feminism is a force created for social, political and economic reform borne out of societal oppression.

- Feminism accuses patriarchy to be the source of the social inequalities and injustices confronting the lives of women.

- Feminism aims at rejecting the idea that a woman's relevance is determined by her gender and that women are naturally less intelligent than men.

- Feminism seeks to remedy the injustices and imbalances that women undergo at the hands of a patriarchal society.

\section{OBJECTIVE(S)}

The main objective of the study is to use Chimamanda Adeche's Purple Hibiscus to showcase how the indigenous African educated woman cope with the issue of being assertive in the patriarchal system found in Purple Hibiscus.

Specifically, the study is to:

1. Look at the position of Adeche's Purple Hibiscus and how the text presents the assertive woman through education.

2. Use the text to showcase the challenges faced by the African educated woman living in Africa.

3. Consider how the African educated woman is able to manage her situation of being assertive irrespective of the challenges associated with being educated and assertive in the patriarchal systems found in the African society.

\section{METHODOLOGY}

The study used the traditional library research approach, by using books, publications, articles and other materials, relevant to the topic. Adeche's Purple Hibiscus, (2006) was the primary text analysed. The choice of Adeche's Purple Hibiscus was influenced by how this female creative writer presents education as the pathway to female emancipation. Since this writer has experienced life as an educated woman, her novel paints an interesting reflection on her personal life and a representation on the African educated woman living in Africa. Salient information was gleaned from other texts to consolidate the study.

\section{FINDINGS AND DISCUSSIONS}

Sheila Ruth (1997) ${ }^{12}$ opines "that the misogynist picture of women as inferior, not quite human, incompetent and lacking responsibility and moral aptitude stands as clear justification to the subordination and suffering of women." This image is well displayed in the character of Beatrice, from Adiches's Purple Hibiscus.

\section{The Position of the Uneducated and Unassertive Mind in the African Society}

The novel opens with this sad news, repeated many times throughout the narrative. Things started to fall apart at home when the narrator's brother, Jaja, did not go to communion and Papa flung his heavy missal across the room and broke the figurines that Mama polished often.(p15). Three main characters are named here: Jaja, Papa and Mama. 
The Educated Indigenous African Woman and the Issue of being Assertive as Showcased in Adeche's Purple Hibiscus?

According to the narrative, Mama symbolically represents the figurines while Papa also represents the Missal. It could be argued that the Missal is Papa as the pronoun 'his' shows it, but it is not so with the figurines. If not, the same personal pronoun would have been used. The definite article is used instead. The figurines represent Mama because they are always associated with her or at least mentioned in connection with her. From the text, "The missal missed Jaja completely and hit the glass étagère which Mama polished often." (p15).

Another instance to show that the figurine represents Mama is the attention the narrator notes, she gives to the figurines:

"Mama stood hugging herself in the center of the living room, near the glass table, until Sisi brought a plastic bowl of water and a kitchen towel. The étagère had three shelves of delicate glass, and each one held beige ballet-dancing figurines. Mama started at the lowest layer, polishing both the shelf and the figurines." $p 43$.

The picture created here symbolizes the fragile Beatrice. The shelves of delicate glass represent Beatrice and the continuous brutalities meted out to her and her children in the novel.

The novel presents the preoccupation of African women writers and their role of redefining African womanhood, representan authentic personality, different from what was portrayed by male writers who dominated theliterary scene in Africa and designed its landscape. Beginning from the colonial perception of the African womanhood as seen in Chinua Achebe's Things Fall Apart (1949) ${ }^{13}$ and J.M. Coetzee's Waiting for the Barbarians, $(1948){ }^{14}$, the depiction is typical in the stereotype of an oppressed and subjugated wife who has little, if any say in shaping her destiny or changing the system that deprives and oppresses her. It is this depiction that Adiche's Purple hibiscus tries to use education of the female character to crush.

The narrative voice in Adiche's Purple Hibiscus presents Beatrice as an unthinking, uncritical and helpless being.

God is faithful. You know after you came and I had the miscarriages, the villagers started to whisper. The members of our ummuna even sent people to your father to urge him to have children with someone else. So many people had willing daughters and many of them university graduates, too. They might have borne many sons and taken over our home and driven us out, like Mr. Ezendu's second wife did. But your father stayed with me, with us. (p31.)

The tone of the narrative is pity. It is seen from the soft voice of the narrator as she explains how grateful Beatrice is when she discusses with Kambili, her daughter, about her husband's faithfulness and how she had been able to conceive again. It could be argued that the writer showcases a faithful husband. This line is explained to mean that a man's heart beat is for a wife to bear him children (male children especially) to continue his lineage. This assertion is supported by several authors including Stephanie Kimou $(2013)^{15}$ who states "that African men want kids, usually lots of them especially male children. They want a woman who will take pride in bearing multiple children..."

However, the narrator's attitude is negative. She is not happy about the lack of confidence with which Beatrice speaks. Beatrice does not speak with analytic mind. Beatrice considers what is right from the dictates of society regardless of what is good for her and her health. She should have thought critically about her health before conceiving again. It is stated categorically in the text that she had had series of miscarriages all in the name of giving another male child to her husband who is also considered as the main cause of her miscarriages. The narrator recounts that he sometimes brutalizes hereven when she is pregnant. 
The Educated Indigenous African Woman and the Issue of being Assertive as Showcased in Adeche's Purple Hibiscus?

I was in my room after lunch, reading James chapter five because I would talk about the biblical roots of the anointing of the sick during family time, when I heard the sounds. Swift, heavy thuds on my parent's hand carved bedroom door. I imagined the door had got stuck and Papa was trying to open it. If I imagined hard enough, then it would be true. Isat down, closed my eyes and started to count. Counting made it seem not that long, made it seem not that bad. Sometimes it was over before I even got to twenty. I was at nineteen when the sound stopped. I heard the door open. Papa's gait on the stairs sounded heavier, more awkward, than usual.

I stepped out of my room just as Jaja came out of his. We stood at the landing and watched Papa descend. Mama was slung over his shoulder like the jute sacks of rice his factory workers bought in bulk at the Seme Border. He opened the dining room door. Then we heard the front door open, heard him say something to the gate man, Amadu.

"There's blood on the floor," Jaja said. "I'll get the brush from the bathroom."

We cleaned up the trickle of blood, which trailed away as if someone had carried a leaking jar of red water colour all the way downstairs. Jaja scrubbed while I wiped.

The narrator explains how serious the brutalities meted out to Beatrice are, using the metaphor, "The swift heavy thuds on the door."According to the narrative voice, Beatrice represents the door and how Papa beats her, as explained signifies that he does not even see her as a human being.

This line could be used to explain why he can give her those heavy thuds that could be counted up to twenty sometimes. What makes Beatrice's situation so disheartening is how the narrator has to imagine that "the door had got stuck and Papa was trying to open it."

Beatrice is presented as so helpless that she is likened to "jute sacks of rice Papa's factory workers bought in bulk at Seme Border." The effect of using this simile is to present the woman who does not think critically before handling matters (that could even affect her life) as so useless that rice sacks, (food that has been purchased in large quantities) is used to describe her. Beatrice would not have been presented in this manner if she was economically empowered through education. She could at least subject her mind to analysis to determine if trying to produce a child at that point in time was conducible before becoming pregnant in the first place. If she had a room of her own, in which to think and decide which way is best for her, she wouldn't go through this helpless situation.

She is again reduced to the level of her own husband's factory workers. This line could be explained to mean, that when rice sacks are packed, the way they are dumped at the place where they are supposed to be packed together, is done as if the content is useless. For these sacks to be packed by the factory workers and not her husband himself, who of course is not expected to do this because of his presentation as a rich, educated man, explains her association with those workers and not the husband himself. This means, however, a reduction of her level to the same level as her husband's workers. This situation also portrays that her husband considered her so inferior to come to his level. What makes her situation more painful is the mention of blood stains on the floor that is cleaned by her children. The use of "blood" here can also be perceived to mean how dangerous the uncritical mind is to womanhood. This is because according to T. K. Abbey et'al, (2008) ${ }^{16}$ blood signifies danger, destruction and a break in the body's ability to defend itself against diseases. The fact is that if someone is wounded, transport of oxygenated blood to all parts of the body cannot occur. This causes the body to loss its ability to defend itself. 
The Educated Indigenous African Woman and the Issue of being Assertive as Showcased in Adeche's Purple Hibiscus?

Beatrice's character showcases how threatened and how inferior the uneducated and unassertive woman's life could be. Though she has a male child already, she feels threatened and always inferior about her situation of not having more than one son. This stereotype of the African female feeling inferior within while projecting the husband is not unfamiliar. It has been variously recreated by African male writers, who always regard women as being led by men, thus justifying their subsidiary position. The only time Beatrice expresses her opinion on issues, she seeks to remain within the stereotype of the African women:

Let me stay in the car and wait, biko," Mama said leaning against the Mercedes. I feel vomit in my throat. Papa turned to stare at her. I held my breath. It seemed a very long moment, but it might have been only seconds.

Are you sure you want to stay in the car? Papa asked. Mama was looking down, her hands were placed on her belly, to hold the wrapper from untying itself or keep her bread and tea breakfast down. My body does not feel right," she mumbled

"I asked if you were sure you wanted to stay in the car. Mama looked up. "I'll come with you. It's really not that bad." Papa's face did not change. He waited for her to walk towards him, and then he turned and they started to walk to the priest's house (p38).

The narrative voice recounts with pity how the unassertive mind is so dependent that the novel showcases Beatrice to depend on her husband for everything. Beatrice is described as one who speaks without confidence even when she has to talk about what concerns her own life. She is presented as an obedient child at the mercy of her parents. This is captured from how "Mama was looking down; her hands were placed on her belly, to hold the wrapper from untying itself or keep her bread and tea breakfast down."Afterwards, when they get home, Beatrice, who had been treated like a little girl by this callous husband before her own children, offers to serve (Papa's) tea though from the text, though it is not her duty to serve Papa's food.

"Papa placed his missal and bulletin on the dining table and sat down. Mama hovered by him. Let me pour your tea," she offered, although she never served Papa's tea. Papa ignored her and poured his tea, and then he told Jaja and me to take sips"(p39).

Despite Papa's misdemeanours as catalogued in the novel, Beatrice at no point makes a comment, a reprimand, or an assessment of the circumstance surrounding the inhuman treatment meted out to her. The narrator uses the word "hovered" which means to stay somewhere because you are waiting to do something or it could mean because you cannot decide what to do. This word is usually used around a bird, an insect or probably an aircraft. Both animals have a characteristic of living by their instinct. Though they have a kind of reason capacity limited to their level of ability, they do not have the reason or thinking capacity endowed with humans to decide on what to do at a particular point in time. They hover around looking for either food or resting place. They usually do not have a specific focus as to where exactly they have to go to find food and sometimes shelter. It is when they find a place favourable and conducive for their living; they stay there. They only move from that environment again when they feel the place is no more conducive for their stay. They do not stay at one place because they have to stay there. They live by instinct and do not have focus.

The aircraft, which is an inanimate object, depends on the pilot for its movements. Upon landing at a particular destination, the pilot himself who is considered to have thinking capacity as a human being, and is supposed to take a decision, depends on the control tower to give a signal that it is safe for landing. If information goes that landing is not safe, it needs to hover until it is safe for landing. In other words, the aircraft is also controlled. For Beatrice to be said to hover by Papa gives the picture of dominance and inferiority.

American Research Journal of English and Literature

Page 6 
The Educated Indigenous African Woman and the Issue of being Assertive as Showcased in Adeche's Purple Hibiscus?

It could be realized from how the narrator describes Beatrice that her character is presented with a tone of disapproval. From the very onset, Beatrice has been likened to inanimate objects. This is to emphasize the fact that there is a voice advocating for women to come out of their slumber to listen and to consider the idea of being assertive. Her inability to think makes her unable to question her situation or criticize her husband's wicked and autocratic tendencies. Of course, patriarchy has little or no place for women. As Coleman Gervas $(2011)^{17}$ asserts:

The positive aspects of patriarchy in particular are largely targeted towards men. Men are still those who hold the high offices in church, in school, etc while women continue to do domestic chores and featured only as shadowy beings that served the sexual and other needs of men.

It is probably due to such situations pertaining in our patriarchal African societies that Adiche's Purple Hibiscus showcases the behaviour of those Beatrices and attempts to present this with disapproval.

\section{The Redemptive Operations of the Uneducated and Unassertive Mind}

In Purple Hibiscus, Ifeoma seems to have a mind of her own. Sheila Ruth (1997) ${ }^{18}$ asserts that this type of woman is

The one who respects both her womanhood and her humanity. She takes her direction and definition from values that are her own, borne of her own selfperceived qualities and goals as well as those of other women. She contributes to society that which she takes to be meaningful and does so in her own way.

Ifeoma here is used to support one of the pillars of feminism that aims at rejecting the idea that a woman's relevance is determined by her gender and that women are naturally less intelligent than men. An assertive woman is that woman who has formal education and this kind of formal education is combined with a mind, that when exposed to levels of oppression, refuses to be submerged. This is the mind that craves for liberty and recognition. Such a mind, fueled by exposure from formal education, strategizes to oppose all forms of oppression. The narrator expresses these character traits about Ifeoma through how she presents her during a conversation between Ifeoma and Beatrice.

The people in his 'ummuna' said he left money somewhere and I have been hiding it. Last Christmas, one of the women from their compound even told me I had killed him. I wanted to stuff sand in her mouth. Then I thought that I should sit her down and explain to her that you do not kill a husband you love, that you do not orchestrate a car accident in which a trailer runs into your husband's car, but again, why waste my time? They all have the brains of guinea fowls. (p82)

From the illustration above, it could be argued that about five clauses are placed in one sentence and this is unusual. But there is significance to this. It symbolizes the strength and guts that education can offer a woman and the process of the educated mind; thinking, analytic and questioning. Before Ifeoma takes a decision, she subjects her mind to analysis. Because Ifeoma's mind is schooled she has the ability to perceive things and decide which one is acceptable.

It is clear from the entrenched African position of accusing almost every wife of killing the husband anytime the husband dies first. Instead of restricting herself to the conscience of society, (that is, she being the one who killed her husband) Ifeoma takes the matter from an objective point of view. Being angry here explains how bold she is. Since situations like this has always been the norm, the woman at this point is supposed to "behave 
The Educated Indigenous African Woman and the Issue of being Assertive as Showcased in Adeche's Purple Hibiscus?

well" in order to respect her in-laws (at the expense of her own feelings.) She did not decide to go according to the norm because she is assertive. At first she "wanted to stuff sand in her mouth" but she "thought" and the "thought" here signifies an analytic mind in action. Ifeoma wanted to educate her in-law about the idea of opposing oppression as women. This could happen because Ifeoma is a university teacher. She again reasons that she shouldn't waste her time because of how entrenched her in- law is to the prescribed customs. This explains the correlation between her and the uneducated woman. The narrative voice here presents the issue figuratively with the use of "the mind of a guinea fowl." Guinea fowls like birds, as explained earlier, do not have a reason capacity to be objective about a matter. Since birds in general move by instinct and can be accustomed to any favourable environment, so are people, who are likened to this little mind, behave. They are moved by what society chooses to be right and not what they feel is right. Ifeoma therefore needed to ignore her, not because she cannot fight her but to point out the difference between the educated, assertive mind and the uneducated and unassertive mind. The boldness of this university lecturer in evaluating the worth of her womanhood is unique. Kambili describes her character with surprise."I could not tear my ears away. It was the fearlessness about her, about the way she gestured as she spoke, the way she smiled to show that wide gap". (p84)

The narrator explains this metaphorically. Ones ears cannot be cut away from ones' head if it is presented literally. But it is described that Kambili could not tear her ears away. The picture presented here describes how one cannot just ignore Ifeoma's speech. Because she is a teacher she knows how to use gestures to appeal to her hearers to understand what she means by what she says. It is explained that even her smile attracted attention because she had a denture that is attractive. The word "wide gap" as used here, can also be extended to mean the space that is created between the educated, assertive woman and the uneducated docile woman any time Ifeoma had to speak and show that smile which is accompanied by her denture. Kambili adds that:

Her laughter floated upstairs into the living room, where I sat reading. I had not heard it in two years, but I would know that cackling, hearty sound anywhere. Aunty Ifeoma was as tall as papa, with a well - proportioned body. She walked fast like one who knew just where she was going to do there. And she spoke the way she walked, as if to get as many words out of her mouth as she could in the shortest time. (p79)

Floated is used to mean freedom. Just as materials that fall in water cannot sink to the bottom, so is Ifeoma's laughter which is described metaphorically as floating to the tune of giving attention to itself from the bottom to the top. It is explained by Kambili that the laughter floated upstairs where she sat reading. If a kind of laughter could interrupt ones reading, then it means that such laughter has purpose and such a laughter that can halt every activity could be said to mean assertiveness.

Kambili again relates Ifeoma to Papa with the use of simile. The effect is to raise the woman to have the same standing with a man. The fact is that right after this comparison she explains how Ifeoma walks and talks fast. When one walks and talks fast it could mean that this person has focus and is informed about what one is doing. Such occurrences show education and assertiveness. The imagery created here about Ifeoma affects the movement of women from the margins and inaction to the center, that is from being outsiders to becoming insiders, from being and feeling victimized and neglected to actually becoming the prime actors in all spheres of life in the society. The writers' vision is to give brains, critical sensibility and voice to Ifeoma among contemporary African women. It also emboldens the Beatrices to resist being coerced by society into subjugating themselves in marriage. Ifeoma frees herself and thereby rejects the miserable fate of what her mothers and grandmothers before her who were silent and were consequently devastated by the exploitative system. The awareness of what her fore mothers experienced actually animates her to demand of her brother the freedom to allow her own nuclear family relate freely with that of her brother's.

American Research Journal of English and Literature

Page 8 
The Educated Indigenous African Woman and the Issue of being Assertive as Showcased in Adeche's Purple Hibiscus?

Kambili, the authorial mouthpiece of this very text, again expresses this situation with surprise. She describes the surprise and fear that gripped her any time aunty Ifeoma calls her papa:

'Eugene'. Aunty Ifeoma called out. "I was saying that Jaja and Kambili should spend some time with me and the children tomorrow." Papa grunted and kept walking to the door. "Eugene!"

Every time Aunty Ifeoma spoke to Papa, my heart stopped, then started again in a hurry. It was the flippant tone; she did not seem to recognize that it was Papa, that he was different, special, I wanted to reach out and press her lips shut and get some of that shiny bronze lipstick on my fingers. $p 85$

The illustration here deals with one of the tenets of feminism. It explains that feminism seeks to remedy the injustices and imbalances that women undergo at the hands of a patriarchal society. This illustration used here could be termed as Grammar meeting literature. The exclamation used after the call could be extended to mean that she sees Papa as her Co equal. Ifeoma, calling Eugene in that manner, could be described to mean that both of them are children from the same womb and so has the right to relate freely with her own brother. Unlike Ifeoma, Beatrice who sleeps on the same bed with Eugene, (and this relationship which goes beyond sleeping together), should make her relate freely with her husband. But she could not bring herself to relate freely before him but remained as a slave or probably a mere child before him. It could be argued that all daughters, mothers and grandmothers who are found under the strictures of patriarchy will consider this behavior as disrespectful as Kambili did. But if humanity understands that God loves and values man and woman equally and desires for them to be fulfilled as individuals, then Ifeoma being a woman can insist on an answer to a question asked when there is no proper response. This is what a lot of African women fear to do due to their control by patriarchy. Ifeoma, on the other hand is portrayed as the willing target of the educated, assertive woman. With her empowerment through education, she was able to manage her home even after the death of her husband:

I have brought out my old kerosene stove," she continued. "It is what we use now; we don't even smell the kerosene in the kitchen anymore. Do you know how much a cooking - gas cylinder costs? It is outrageous! Mama shifted on the sofa. "Why don't you tell Eugene? There are gas cylinders in the factory... Aunty Ifeoma laughed patted Mama's shoulder fondly. "Nwunyem, things are tough, but we are not dying yet. I tell you all these things because it is you. With someone else, I would rub Vaseline on my hungry face until it shone. (p84.)

From this quotation, Ifeoma is seen to transform her education into economic independence. Though her husband is dead she did not depend on her rich brother for anything. She could use her mind for alternatives when she felt she could not afford a gas cylinder for her cooking.

This discussion is in tandem with one of the theories of feminism which indicates that feminism is a force created for social, political and economic reform borne out of societal oppression. Because of her schooled mind, she could manage the kerosene stove to her advantage so that it did not even smell. Even when her sister in law brought her mind unto the fact that she could obtain one from her brother for free, she did not agree. Ifeoma's portrayal here is that of sisterhood which is also another pillar of feminism that strengthens womanhood. This is shown through Ifeoma's gentle pat on Beatrice's shoulder, the use of a local name "Nwunye m" which means our wife and metaphorically talking about "rubbing Vaseline on her hungry face until it shown." Ifeoma did not use her education in a suppressive manner. She brings Beatrice to her level and with the use of this local content explains matters to her using a graphic picture to make her understand things better. Because she is a 
The Educated Indigenous African Woman and the Issue of being Assertive as Showcased in Adeche's Purple Hibiscus?

teacher herself, she does it so well by going beyond the sensory perception. The narrative voice in this situation, debunks the idea about men who take the responsibility of the needs of women and at the end own their brains and cause them to remain in perpetual subjugation as instituted by patriarchy.

Ifeoma is used to establish the fact that "since men have learnt to shoot without missing, women have also learnt to fly without perching." The narrator presents her strong and jubilant character, through how she translates her knowledge into bringing about freedom, peace and harmony with an inner quality of blending tradition and modernity which helped her children to associate well with others and especially with their own Papa Nnuku who had been considered a heathen by Eugene and his family. This is evident at the time when Aunty Ifeoma tried to reorient Kambili's mind of her father's education about a heathen.

'How can Our Lady intercede on behalf of a heathen, Aunty?': Aunty Ifeoma was silent as she ladled the thick cocoyam paste into the soup pot; then she looked up and said Papa- Nnuku was not a heathen but a traditionalist, that something that was different was just good as what is familiar, that when Papa Nnuku did itu-nzu, his declaration of innocence, in the morning, it was the same as our saying the rosary."(p173).

"She ladled the thick cocoyam paste into the soup here" is perceived to mean how Ifeoma gradually helped Kambili with an explanation to free her mind about her father's education of a heathen. Because her mind is schooled, she knows how to use graphical representations that is able to appeal to the senses of her listeners. She makes them understand the meaning of what she says because she takes time to think or find reason for her actions before she acts. Re orienting a child's mind from an entrenched position that has also been given by nobody than her real father whom she trusts so much was not an easy thing to do at all. However, Ifeoma was able to present what she says in a manner that is able to sink into other minds and makes what she says accepted, understood and appreciated through the use of going beyond the sensory perception. This is the educated woman in action. It is significant to note that this same quotation also symbolizes the blend of tradition and modernity. Her position as a teacher aided her thinking capacity (of comparing Papa Nnuku's itu- nzu, his declaration of innocence, in the morning, and the saying of the rosary.) It is Ifeoma's ability to blend tradition and modernity that encouraged freedom, peace and harmony reflected in her children's composure.

She walked and talked even faster and with more purpose than Aunty Ifeoma did. Only her eyes were different; they did not have the unconditional warmth of Aunty Ifeoma's. They were quizzical eyes, eyes that asked many questions and did not accept answers. Obiora was a year younger, very light skinned, with honey - coloured eyes behind thick glasses, and his mouth turned up at the sides in a perpetual smile. Chima had skin as dark as the bottom of a burnt pot of rice and tall for a boy of seven. They all laughed alike: throaty, crackling sounds pushed out with enthusiasm. (p86.)

Aunty Ifeoma's assertiveness is seen here to be extended into her children due to how she is pictured to present her beliefs through figurative analysis. Amaka is compared to her mother and this showcases how assertive and confident she has also become. The narrator pauses with a 'but' which puts Amaka into the learning process. Amaka's quizzical eyes as used here, also expresses an examination or an insight into a situation and the ability to determine freely which one to belong to or accept as right. It again symbolizes Amaka's quest for knowledge. It is her education that quickens her ability to look at things from a very objective point of view. It could be argued that the happy atmosphere created by Ifeoma explains why her children, do things with enthusiasm unlike Beatrice's children who live within themselves. The fact that she is a teacher gives her the advantage of 
The Educated Indigenous African Woman and the Issue of being Assertive as Showcased in Adeche's Purple Hibiscus?

helping her children to have the quest for knowledge. Obiora's "honey coloured eyes behind thick glasses" could be extended to mean her quest for knowledge. It is this same atmosphere about Ifeoma that makes Papa Nnuku, a custodian of customs, relate freely with Ifeoma's children without malice. An example is the conversation that took place when Ifeoma and her children and Papa Nnukwu went for sightseeing.

He likes to talk about dying soon,' Amaka said, in amused English. He thinks that will get us to do things for him...' Dying soon indeed. He'll be here when we are as old as he is now,' Obiora said in equally amused English. What are those children saying, gbo, Ifeoma?' Papa Nnukwu asked. 'Are they conspiring to share my gold and many lands? Will they not wait for me to go first?' If you had gold and lands, we would have killed your years ago ourselves," Aunty Ifeoma said. My cousins laughed, and Amaka glanced over at Jaja and me, perhaps wondering why we did not laugh, too. I wanted to smile, but we were driving past our house just then, and the sight of the looming black gates and white walls stiffened my lips ( $p$ 90).

The narrative voice uses the word "amused English" to explain the manner of the conversation in the car. All they discussed in the car were done using ironic statements. Those statements used are so amusing that it is only those who live within themselves and are also tongue tied like Beatrice's children who will not be amused by such statements. This situation shows assertiveness which Ifeoma even relays onto her experiments that gave birth to the purple hibiscus flowers that are found to blossom on her compound. The narrator explains that the freedom, peace and harmony is symbolized by the purple type of hibiscus that was able to flourish on her compound. According to Andre Kabore (2013) ${ }^{19}$, the purple hibiscus symbolizes freedom and fulfillment. It stands for the inner voice and strength that the characters seek for. He continues that the color 'purple' - a mixture of red and blue - represent diversity and variety, multiplicity and unity. These qualities were what Ifeoma was able to exhibit in the novel that helped her children's composure. It is these same qualities that she used to help Kambili and Jaja to come out of their father's dominion.

"There was a shadow clouding Papa's eyes, a shadow that had been in Jaja's eyes. Fear. It had left Jaja's eyes and entered Papa's......"

"Jaja pushed his chair back. "Thank you, Lord. Thank you, Papa. Thank you, Mama."

I turned to stare at him. At least he was saying thanks the right way, the way we always did after a meal. But he was also doing what we never did: he was leaving the table before Papa had said the prayer after meals." (P.22)

The narrative voice here establishes the strength of Ifeoma's intervention that breaks a traditional pattern of dominance. It was after Jaja came back from Nsuka and tried to use some of Ifeoma's experimental breed that he started to show his growing maturity. But it is not that the hibiscus is found in Aunty Ifeoma's house only. The bushes of hibiscuses are found in the vicinity of Kambili's house also. Only that the colors of these plants in the house of the Acheke's were rather reddish which Kabore explains that it symbolizes pain, anger, and the rapid blooming of the red hibiscuses signifies the dominance of Papa. In Enugu, the hometown of the Achike household, the narrator Kambili recounts:

Closer to the house, vibrant bushes of hibiscus extended and touched one another as if they were exchanging their petals. The purple plants had started to push out sleepy buds, but most of the flowers were still on the red ones. They seemed to bloom so fast, those red hibiscuses, considering how often Mama cut them to decorate the church altar and how often visitors plucked them as they walked past to their parked cars. The colors of these plants were reddish and the purple plants had begun to outgrow the buds. 
The Educated Indigenous African Woman and the Issue of being Assertive as Showcased in Adeche's Purple Hibiscus?

The phrase, "The vibrant bushes of hibiscus extended and touched one another as if they were exchanging their petals" as used here symbolizes a traditional pattern of dominance. The symbolism used here is based on the fact that petals are the brightly coloured parts of flowers that attract insects. Because of their good smell, insects visit them in search of food. In this process, pollen is taken from one flower onto another flower in order to help it to produce seed-pollination. This explains that petals are not exchanged. They are rather exposed. The link therefore is that since the members of the Achike family were not allowed exposure to the environment in order to explore and be informed about the realities of life, as petals are exposed in order for pollination to occur, they were not able to relate well with the realities of the world until Nsuka did it all. (This pattern of dominance is the kind Papa uses in the Acheke family to silence every living soul in the house to live as a shadowy being.) Papa owns their souls in such a way that in trying to correct what he sees not good about their lives as presented in "pushing out sleepy buds" he rather puts fear into them through his harsh manner of trying to correct them until Jaja comes with the purple type of hibiscus from Aunty Ifeoma's compound that opens their eyes to freedom. This, the narrator explains with the use of personification to effect the fact that Jaja and Kambili were gaining life from their animalistic treatment meted out to them through Papa's dominance. Their awakening was possible because at Nsuka, in the compound of Aunty Ifeoma and her children, Kabore explains again that the hibiscus symbolizes action and spiritual awakening. Jaja's gradual awakening from Papa's dominion was so shocking that Kambili's gaze is an expression of her shock as she is not habituated to the bravery shown by her elder brother:

"I turned to stare at him. At least he was saying thanks the right way, the way we always did after a meal. But he was also doing what we never did: he was leaving the table before Papa had said the prayer after meals." (p22.)

I lay in bed after Mama left and let my mind rake through the past, through the years when Jaja and Mama and I spoke more with our spirits than with our lips. Until Nsukka started it all: Aunty Ifeoma's little garden next to the verandah of her flat in Nsukka began to lift the silence. Jaja's defiance seemed to me now like Aunty Ifeoma's experimental purple hibiscus: rare, fragrant with the undertones of freedom, a different kind of freedom from the one the crowds waving green leaves chanted at Square the coup. A freedom to be, to do. (P. 23)

Kambili's mind racking through the past is evidence of the awakening of her reasoning capacity. Aunty Ifeoma's skill of letting her knowledge submerge into other minds has made its way into Kambili. She no more thinks through the line of Papa and feels what Papa feels in order to please Papa. This time around Kambili does a retrospective analysis by thinking through the past to judge through the present. This is what the assertive mind is capable of doing.

\section{CONCLUSION}

In summary, women comprise more than half of the human population and have the numerical superiority to become very powerful. It is however, fortuitous that everything has turned to sideline women from unraveling their God-given talents. A lot of women have however, spontaneously accepted their condition as the tail and not the head.

Education is one of the most critical areas of empowerment for women, the power to decide over their own lives and bodies as well as their children. It is also the power to overcome the fear to open up and be able to speak their minds; voice, their own opinions about issues concerning their own lives.

The study focused mainly on the position of Chimamanda's Purple Hibiscus and used the characters, Beatrice and Ifeoma as the main analytic focus. It could be realized that the effective combination of literary techniques and language bring about a clear and interesting rendition of the story, through this process Chimamanda's 
The Educated Indigenous African Woman and the Issue of being Assertive as Showcased in Adeche's Purple Hibiscus?

readers are able to understand the activities of the characters better and also learn valuable lessons that education can offer a woman. It is realized from the story that education really empowers women economically and quickens self-assertion. Through Aunty Ifeoma, Chimamanda showcases the assertive women by making all round positive analysis around her character but presents Beatrice's character with disapproval. She tries to place these two women before her readers for them to decide the right path to take if the female is supposed to be relevant to the African society. The role played by Ifeoma explains how bold and proactive a woman could be when she is empowered through education. This suggests that.......

\section{END NOTES}

1. Nwapa, F. (2007). Women and creative writing in Africa. In T. Olaniyan \& A. Quayson (Eds.), African literature: An anthology of criticism and theory (pp. 526-532). Oxford, UK: Blackwell Publishing Ltd.

2. Flora Nwapa's Efuru Pearson Educational limited, United states of America(1966)

3. Buchi Emecheta's The Joys of Motherhood, Allison \& Busby, Nigeria(1977)

4. Mariama Ba's So Long a Letter Harlow, UK: Heinemann. (1979)

5. Ama Atta Aiddoo, Changes, New York, Feminist Press, (1993).

6. Ba's Scarlet SongHeinemann, Cameroon.(1981)

7. Emecheta's Double Yoke Allison \& Busby, Nigeria(1982).

8. Aidoo's Changes,(1991) Supra

9. Ama Darko's FacelessSub-Saharan publishers, Legon, Accra (2003)

10. Chimamanda' Adichie, Ngozi. Purple hibuiscus, Lagos, Kachifo Limited. and Unwin. (2006)

11. Wolf, Virginia, A room of one's own Wollstonecraft Mary (1792). Vindication of the Rights of women.

12. Sheila Ruth. (1997). Issues in feminism: an introduction to women's studies, California, Mayfield Publishing Company.

13. Achebe, Chinua., Things Fall ApartLondon: Heinemann Educational Books Ltd (1958)

14. Maxwell, Coetzee, J.,Waiting for the Barbarians, Secker \&Warburg South Africa. Cape Town(1948)

15. Abbey, Tweneboah, K, et al., Integerated Science for Senior High Schools, Unimax Macmillan Ltd., 2008.

16. Kimou Stephanie, African Men Don't Do Feminists, Voices of Africa. (2013)

17. Coleman, Gervais. On their Own and in their Own Words: Bolivian Adolescent Girls' Empowerment through Non-Governmental Human Rights Education. Journal of Youth Studies vol., 14, no., 2, 2011, pp. 23-61.

18. Sheila Ruth. (1997). Issues in feminism: an introduction to women's studies, California, Mayfield Publishing Company.

19. Andre Kabore. (2013). "The Symbolic Use of Palm, Figurines and Hibiscus in Adichie's Purple Hibiscus." Linguistics and Literature Studies1 32-36.

\section{REFERENCES}

1. Adichie, Chimamanda, A. Purple Hibiscus, Lagos, Kachifo Limited, 2006.

2. Abbey, Tweneboah, K, et al., Integerated Science for Senior High Schools, Unimax Macmillan Ltd., 2008.

American Research Journal of English and Literature

Page 13 
The Educated Indigenous African Woman and the Issue of being Assertive as Showcased in Adeche's Purple Hibiscus?

3. Anderson, Arnoldet. al,The Feminist Face of God: The Unfolding of the Sacred in Women, New York, Bantam Books, 1991.

4. Arnot, Mary. "The Complex Gendering of Invisible Pedagogies: Social Reproduction or Empowerment?" British Journal of Sociology of Education, vol. 23, no. 4, 2002, Pp. 211-217.

5. Ba, Mariama. (2008). So Long a Letter. Harlow, UK: Heinemann.

6. Coleman, Gervais. "On their Own and in their Own Words: Bolivian Adolescent Girls' Empowerment through Non-Governmental Human Rights Education". Journal of Youth Studies vol., 14, no., 2, 2011, pp. 23-61.

7. Cuddon, John, A. A Dictionary of Literary Terms and literary Theory (3rd ed.). Oxford, Blackwell, 1991.

8. Darko, Amma. Faceless, Accra, Sub-Saharan Publishers, 2003.

9. Deininger, Karl. "Does Cost of Schooling Affect Enrollment by the Poor?" Universal primary education in Uganda. Economics of Education Review, vol., 22, no., 3, 2003, pp. 291-305.

10. Dierks, Benjamin. "The UN Fourth World Conference on Women" NWSA Journal, vol. 8, no., 2, Department of Public Information, New York, 1996.

11. Emecheta, Buchi. (2007). "Feminism with small "f"!. In T" Olaniyan \& A. Quayson (Eds.), African Literature: An Anthology of Criticism and Theory, Oxford, UK: Blackwell Publishing Ltd. Pp. 551-557.

12. Harry, Buroud: The Making of Masculinities: The New York Men's Studies, Boston, Allen and Unwin, 1987.

13. Kimou, Stephanie.African Men Don't Do Feminists, Oxford, Blackwell publishing Ltd., 2013.

14. Kabore, Andre. "The Symbolic Use of Palm, Figurines and Hibiscus in Adichie's Purple Hibiscus" Linguistics and Literary Studies, vol. 2, no. 1, 2012, pp. 32-36.

15. Maxwell, Coetzee, J., Waiting for the Barbarians, Cape Town, Secker \& Warburg, 1948.

16. Nwapa, Flora."Women and Creative Writing in Africa”. In T. Olaniyan \& A. Quayson (Eds.), African Literature: An Anthology of Criticism and Theory, Oxford, UK: Blackwell Publishing Ltd., 2007, pp. 526-532.

17. Ogundipe-Leslie, M., “Stiwanism: Feminism in an African Context”. In T. Olaniyan \& A. Quayson (Eds.), Africa Achebe, Chinua., Things Fall Apart London: Heinemann Educational Books Ltd.,1958.

18. Ruth, Sheila Issues in Feminism: An Introduction to Women's Studies, California, Mayfield Publishing Company, 1983.

19. United Nations Development Programme, Human Development Report, New York, 1995.

20. Walker, Alice. In Search of our Mothers' Garden: Womanist Prose. San Diego: Harcourt Brace Janovich, 1983.

Citation: Georgina Brookman-Andoh, Martin Gyekye-Ampofo, "The Educated Indigenous African Woman and the Issue of being Assertive as Showcased in Adeche's Purple Hibiscus?" American Research Journal of English and Literature, vol 4, no. 1, 2018, pp. 1-14.

Copyright (C) 2018 Georgina Brookman-Andoh, Martin Gyekye-Ampofo, This is an open access article distributed under the Creative Commons Attribution License, which permits unrestricted use, distribution, and reproduction in any medium, provided the original work is properly cited. 